\title{
Disposition Role on Adolescent Reproduction Health Policy Implementation
}

\author{
$1^{\text {st }}$ F Handayani \\ Sekolah Tinggi Ilmu Kesehatan \\ 'Aisyiyah Bandung \\ Indonesia \\ fatiah79@gmail.com
}

\author{
$2^{\text {nd }}$ A Kamila \\ Sekolah Tinggi Ilmu Kesehatan \\ 'Aisyiyah Bandung \\ Indonesia
}

\author{
$3^{\text {rd }}$ Nurhayati \\ Sekolah Tinggi Ilmu Kesehatan \\ 'Aisyiyah Bandung \\ Indonesia
}

\begin{abstract}
Indonesian data currently shows that there are problems that threaten adolescents, namely sexuality, HIV/AIDS and NAFZA. The existence of flow and incentives for policy managers can improve the performance of managers and policy implementers in the time available. This study aims to analyze disposition of policies to support the success of adolescent reproductive health education. This research is a descriptive exploratory study to describe phenomena systematically. Subjects of informant research are recipients of adolescent reproductive health education, implementers and policymakers. The sampling technique used is a purposive sampling technique. Data collection is done by observation, interview and documentation techniques. Data analysis includes processing the interview data in the form of transcripts, coding and data reduction, presenting data in the form of themes and interpreting and drawing conclusions from the results of the analysis. Commitment of teachers and principals in implementing learning about adolescent reproductive health as well as the incentive aspect of being given incentives for teachers who provided material or were involved in activities even though the nominal was not mentioned. Other aspects of the assessment are needed to assess the commitment of policy implementers and policy makers such as the values held by each party in implementing policies.
\end{abstract}

Keywords-implementation, adolescents reproductive health, policies

\section{INTRODUCTION}

The Indonesian people have been facing adolescent reproductive health problems that have not ended yet. Adolescents and young people as productive people must preparebeforehand so that they are physically and mentally able to deal with problems, both themselves and problems in their surroundings. At present, the basic problems of adolescent reproductive health are sexuality, HIV / AIDS and NAFZA or known as the Three Basic Threats of Adolescent Reproductive Health (TRIAD KRR) which still shows a poor condition. The results of the study of Adilah et al. (2017), showed that from a sample of adolescents, 1419 had had sexual relations, with and without condom protection during sexual intercourse [1]. According to data from UNAIDS cited by Utami (2018) in Indonesia, the incidence of HIV reaches 0.19 per 1000 population. Indonesia is the third-highest number of PLHAs, and new cases of infection in the Asia Pacific region after India and China [2 ] The death rate due to AIDS in Indonesia also increased steadily up to $68 \%$ in 2016 so that it has an impact on the severity of the challenges of the Indonesian people to achieve the goal of Sustainable Development Goals (SDG's) in 2030. Transmission of HIV / AIDS described in the exposure of Utami $S$ research (2018) revealed that disease transmission focusedon key population groups, one of which is NAFZA injection users.

Various studies and literature reveal the complexity of reproductive health problems in adolescents with other influencing factors such as social, economic, cultural factors including government policies in addressing the reality of adolescent reproductive health. The lack of access to education and adolescent reproductive health services is the duty of the government to hold equal distribution as stated in The Law No. 52 of 2009 concerning Population Development and Family Development that attempts to improve the quality of adolescents are made through providing access to information, education, counselling and services about family life. This service is in the context of fulfilling important elements, namely understanding about reproductive rights, maturing individual responsibilities and individual rights to obtain knowledge from services given [3].

The process of implementing a reproductive health education program is to realize Tegar Remaja, which is to make teenagers who behave healthily avoid the risk of KRR TRIAD, which is also a policy. Policy according to Iskandar quoted by Ramdhani $\mathrm{A}$ and Ramdhani MA (2017), is defined as a series of program plans, activities, actions, decisions, attitudes, to act or to not act carried out by the parties (actors), as part of problem-solving faced [4] and implementation of the Policy is defined as an implementation of the decision of a plan, whether it is executive, legislative or judicial or as stated by Van Meter and Van Horn [5] thatpolicy implementation is actions carried out either by individuals or officials or groups of government or private, which aimed at achieving the 
objectives outlined in the policy decision. The implementation of reproductive health policy is an attempt to achieve national development goals through population control and health which currently focuses on fulfilling individual reproductive rights rather than merely solving population and development problems [6]. Population policy, family development, including reproductive health, is currently managed by the National Population and Family Planning Agency (BKKBN) which reports directly to the Ministry of Health. Along with the development of the current conditions, BKKBN's delegation of tasks and authority has changed from a vertical agency to an autonomous agency combined in the district/city with offices/agencies from various sectors in the region.

The change in the agency has created problems, one of which is the decline in the performance of family planning managers and officers in the regions, the lack of human resources and the lack of sustainability of programs that also involve religious leaders. Declining performance results in the low commitment of officers and managers, both commitment of staff and financial support for family planning programs. This condition is a challenge for reproductive health policy which is quite significant for the progress of the development of reproductive health policy because there is involvement of other sectors such as education, social, religion, empowerment of women and children, as well as youth and sports [6].

The results of previous studies by the author show aspects of positive disposition in the implementation of reproductive health education in one junior high school in Bandung Regency. According to the policy theory of George Edward (1980) cited by Arief et al. the factors that influence the success of the policy are communication, resources, bureaucratic structure and disposition factors. The purpose of this study is to analyze the role of disposition towards the implementation of health policy, including aspects of commitment and incentives for policy implementers [5].

\section{METHOD}

This research is qualitative research to describe a phenomenon systematically. Research Subjects are policymakers and implementers of policies regarding the learning of adolescent reproductive health or called a feminism program, namely teachers and principals. The samples involved were five teachers and two principals. The research locations were Muhamamdiyah 4 Margahayu Middle School and Aisyiyah Rancaekek Middle School in Bandung Regency. Data collection is done through observation, interviews and documentation studies, the data are analysed with the stages of transcription, coding, and data reduction then the data is presented in the form of themes and conclusions are drawn.

\section{RESULT}

In this study, researchers divided the results of the study into two main themes, namely commitment and incentives in implementing reproductive health learning at the study site. The description of the results of the study is as follows:

A. Commitment Aspects in the Implementation of Adolescent Reproductive Health Policies
Based on the results of the study, it was found that learning about reproductive health in SMP Muhammadiyah Bandung district showed a commitment from the implementers of the policy, namely the teachers. The reproductive health learning policy is carried out with good commitment from the school principal, teachers and students. The implementers, teachers in both study sites, have shown a commitment to provide learning about adolescent reproductive health even though the material is limited, and there are no guidelines or manuals. Most respondents convey the same information, even though their educational background is not health, but they run a long-running school program.

The commitment of the implementers was also shown in the respondent's statement about making the presenter's schedule, the schedule is set annuallyand teachers present materials alternately.

B. Incentive Aspects in Implementing Adolescent Reproductive Health Policies

Another aspect of disposition to support the success of policies is the provision of incentives for policy implementers. The results of the research at the two research sites namely Muhammadiyah Margahayu Middle School and 'Aisyiyah Middle School Rancaekek showed the existence of a budget for this activity, as stated by the Student Section of Aisyiyah Rancaekek Middle School that the school makes a program at the beginning of the year as well as its budget in Student Affairs as for other Student Activity Units. As for the report, the Principal of the Junior High School will receive an activity report at the end of the year or if needed at any time.

Incentives for implementers who provide learning material for adolescent reproductive health in the feminism program are given, even though the respondent did not specify the amount and was given according to the schedule of attendance to give the material.

\section{DISCUSSION}

\section{A. Commitment}

Well-prepared policy objectives will be successful if accompanied by policy implementation and evaluation as part of a policy cycle. Actions are needed for the implementation of policies carried out by the government or individuals (or groups), the private sector, and all of theselead to the goals set achievement in a previous policy decision. These actions, one day, try to transform decisions into operational patterns, and continue these efforts to achieve changes, both large and small mandated by individual policy decisions [7].

The results of the study present that the implementation of policies for learning adolescent reproductive health that has been implemented in the feminism program has been carried out, seen from the commitment of all parties namely the principal, teachers, students and parents. Even though the competence of the teacher giving the material is not appropriate, namely the mathematics teacher and the English teacher and there are other teachers, but these teachers who are assigned contributed positively to the sustainability of learning.

Commitment is needed by everyone to reach the goals set. Building commitment requires efforts that must be 
done early on when someone does a job or joins an institution/company or other agency. Agencies must provide positive treatment in order to form a favourable image for everyone involved in it. According to Wacono, quoted by Kusumastuti et al. (2013), two essential things to build commitment are the leadership style shown in daily attitudes or actions and the principle that the action is an essential factor rather than words. Leaders always do something rather than just spit out words or just rhetoric [8].

In a research study by Oliver (2006), it is mentioned that there are fundamental challenges faced when implementing policies. One of them is the implementation responsibilities which sometimes differ in understanding or acceptance among policymakers, for example, from the government and policymakers. Policymakers and policy implementers sometimes have different views. It is better in this condition that the policy implementation process requires cooperation with and through a series of actors and organizations to communicate objectives, availability of resources, sense of ownership of the implementers of the tasks assigned, conflict management and efforts to maintain a positive attitude if there is a change in policy [9].

If there is a change in the program, then efforts should be made to maintain the program by involving all of its contributions from the government or the private sector because sometimes there were delays, renegotiation of resources and responsibilities and confusion among the beneficiaries of the program. One thing to avoid is not to ruin the previously-arranged program. Regarding adolescent reproductive health, according to Meyer \& Herscovitch cited by Widaharthana (2012), commitment is a mindset that binds individually to a series of actions that are relevant to one or several targets [10]. Implementing the policy requires commitment from all parties starting from policymakers and policy implementers as well as the elements involved in it. The results of the study mention the influence of certain people on adolescent access to reproductive health information and services, namely peers, parents and family, teachers and health workers [11].

Hidayat's research results (2010), mention the theory of commitment proposed by Kiesler and Sakumura, namely the existence of a bond to a specific action. Efforts to keep someone a member of a profession or occupation, then that person will believe and accept the values of work and their desires [12].

\section{B. Incentive}

In addition to commitment, incentives are needed as a form of appreciation to those involved in the policy implementation process. According to the results of the study, it shows that the school through the principal's policy budgeted the feminism program budget, including the provision of incentives for the material deliverer even though the nominal amount remained unknown. As for the teachers who did not give the material according to their schedule, they did not receive any incentives. As conveyed in the research of Rochmat et al. incentives can be given in financial (material) and non-financial (non-material) forms reasonably, so that officers who do not carry out their duties do not receive incentives [13]. According to Suad Hunan in
Evi research (2009), incentives are wages given to increase work motivation [14]. Meanwhile, according to Handoko (2002) from the quote Djula B, incentives are stimulants offered to employees to carry out work according to or higher than the standards set [15].

The provision of incentives in the form of money for teachers who provide feminism material is intended as a strategy to increase school productivity and efficiency. The aims are to maintain a positive brand of the school, as well as the school's vision and mission, effectiveness and efficiency in facing increasingly fierce school competition in terms of quality programs for students. As reinforced from the results of Wakito's research cited by Novianty, et al. that monetary incentives can affect work motivation, and serve asan addition to the basic salary that was previously received [16]. Incentives serveas an effort to increase work motivation, in addition to other factors namely the work situation, opportunities for training and self-development, and job security. However, these several factors, the most influencing work performance, especially motivation is the awarding [17].

Related to the number of incentives that remained unknown in the study, whether appropriate or not, then delivered in the research results of Ditlopo, et al. (2013), sometimes in some countries, they have limited guidance on how to implement a financial incentive strategy that will have an impact on achieving goals, for example, there is inequality or unequal treatment, so incentive becomes a problem in decreasing performance and motivation [18]. Based on these results, it is concluded that the success of providing financial incentives depends on the manner and process of implementation.It shows that weaknesses come from they way we see the conditions needed, including good planning and policy management processes, improved communication and coordination, detailed guidelines for implementing policies and indicators in monitoring and evaluating. Although perfect policy implementation is rarely achieved, the provision of financial incentives must be addressed with the opportunity to review, redesign and self-correct the policy itself [18].

\section{CONCLUSIONS}

The success of policies in reproductive health programs depends on the aspect of disposition, including commitment and incentives. Strong commitment from all parties involved can be seen from the schedule of activities that are arranged annually, the availability of material from each scheduled meeting, the responsibility of the principal, as well as the students and teachers who always coordinate to plan the program ahead. The other side of this commitment is not followed by monitoring and evaluation to assess the commitment of all parties. As for the incentive side, it is provided even though the nominal amount or guideline amount givenremained unknown.

The results of this study recommend further research in broader aspects of commitment, for example, the values that each person has to support commitment.

\section{ACKNOWLEDGMENT}

The result of the research is the development of a small study on reproduction health policies funded by the 
Ministry of Research, Technology, and High Education. The author would like to thank all parties involved in this research, especially participants.

\section{REFERENCES}

11] Y. Adilah, R. Mutahar, I. Purnamasari, "Determinan penggunaan kondom pada hubungan Seksual pertama kali oleh remaja belum menikah di Indonesia (Analisia Data SDKI KRR 2012),2017 J. Ilmu Kesehat. Masy., 82

[2] S. Utami 2018 "HIV/AIDS dalam sustainable development goals (sdgs): insiden, permasalahan, dan upaya ketercapaian di indonesia." universitas terbuka

[3] H. M. Sihotang, J. S. Efendi, I. F. D. Arya 2018 "Implementasi program kesehatan reproduksi remaja di kota pekanbaru $J$. Endur. Kaji. Ilm. Probl. Kesehat., 32 260-270

[4] A. Ramdhani, M. A. Ramdhani 2017 Konsep umum pelaksanaan kebijakan publik J. Publik, 11 1 1-12

[5] S. Arief, J. Jumadi, A. Abdullah 2017 Pengembangan model implementasi kebijakan program penanganan anak jalanan untuk pengentasan kemiskinan di kota makasar, in Prosiding Seminar Nasional Himpunan Sarjana Ilmu-ilmu Sosial 2 423-436.

[6] Z. Fatoni, Y. Astuti, A. Situmorang, N. F. N. Widayatun, S. S. Purwaningsih 2015 Implementasi kebijakan kesehatan reproduksi di indonesia: sebelum dan sesudah reformasi," $J$. Kependud. Indonesia 10 1. 65-74

[7] N. R. Zulyanti 2013 Komitmen kebijakan keselamatan dan kesehatan kerja (k3) sebagai upaya perlindungan terhadap tenaga kerja (sudi pada mitra produksi sigaret (mps) kud tani mulyo lamongan) DiA Public Adm. J., 112

[8] A. F. Kusumastuti and H. Nurtjahjanti 2013 Komitmen afektif organisasi ditinjau dari persepsi terhadap kepemimpinan transaksional pada pekerja pelaksana di perusahaan umum (perum) x semarang J. Stud. Manaj. Organ. 10, 1 13-21

[9] T. R. Oliver 2006 The politics of public health policy Annu. Rev. Public Heal. 27 195-233, 2006.

[10] I. P. E. Widaharthana 2012 Pengaruh komitmen terhadap perubahan pada intensi keluar: dengan coping terhadap perubahan sebagai variabel pemediasi Bul. Stud. Ekon.

[11] J. L. Morris and H. Rushwan 2015 Adolescent sexual and reproductive health: the global challenges Int. J. Gynecol. Obstet. $131 \mathrm{~S} 40-\mathrm{S} 42$

[12] M. Hidayat 2010 Analisis komitmen (affective, continuance dan normative) terhadap kualitas pelayanan pengesahan STNK kendaraan bermotor (Studi empiris pada kantor bersama Samsat di Propinsi Kalimantan Timur J. Manaj. dan Kewirausahaan 12 1,11

[13] K. B. Rochmat, D. Hamid, M. S. Hakam 2013 Pengaruh insentif terhadap motivasi dan kinerja J. Adm. Bisnis 11 19-27

[14] T. Evi 2015 Kajian teoritis analisa hubungan pemberian insentif dengan semangat kerja karyawan in Seminar Nasional Informatika (SEMNASIF) 15

[15] B. Djula 2013 Pengaruh pemberian insentif terhadap prestasi kerja karyawan J. Fak. Ekon. dan Bisnis UNG

[16] R. R. Novianty and S. N. Evita 2018 Financial incentives: the impact on employee motivation," Acad. Strateg. Manag. J

[17] N. S. Hafiza, S. S. Shah, H. Jamsheed, K. Zaman 2011 Relationship between rewards and employee's motivation in the non-profit organizations of Pakistan Bus. Intell. J 42 327-334

[18] P. Ditlopo, D. Blaauw, L. Rispel, S. Thomas, and P. Bidwell 2013 Policy implementation and financial incentives for nurses in South Africa: a case study on the occupation-specific dispensation," Glob. Health Action 6119289 